\title{
A NNALS
}

OF

\section{The Entomological Society of America}

\section{A REVISION OF THE GENUS SCIARA OF THE FAMILY MYCETOPHILID $Æ$ (Diptera)}

By F. W. Pettey, Cornell University.

In working over the Cornell University collection of specimens of Sciara, family Mycetophilidæ, thirty-one new species collected in the United States were discovered. Consequently it was thought advisable to revise Dr. Johannsen's Sciara key, found in the Maine Agricultural Exp. Sta. Bull. No. 200, Part IV, pp. 117-123. The work was done under Dr. Johannsen's direction.

Dr. Johannsen, in his classification of the species of the genus Sciara, has divided them into two main groups, those whose wings have setose media and cubitus and those whose wings have no setæ on these veins. Other scientists, in their description of new species of Sciara, have frequently overlooked this important structural character. In an effort to call more particular attention to this feature and to avoid the possibility of neglecting it in the future descriptions, a new genus is proposed for those species having no setæ on the media and cubitus. Since the type species of the genus Sciara, thomce L. (Syst. Nat. Ed. XII, II. 976.39 (Tipula) 1767), has subsequently been found to have setose media and cubitus, those species having this character are left in the genus Sciara.

About half of those species of the male sex under the new genus have a hypopygium with one or two clusters of setæ at the base on the median ventral line. No males of the genus Sciara as above restricted exhibit this character. Although this structure should not be overlooked in the description of a species, it would be inadvisable to make use of it as a generic character, since it cannot be designated in females. 
The larvæ of all those species observed, under the genus Sciara as above restricted, $i$. e., those species possessing setose media and cubitus, have the habit of migrating in a chain-like line. None of the observed larvæ of the Neosciara species exhibit this feature.

\section{Neosciara new genus.}

This genus includes species which would formerly have been placed under the genus Sciara, but which are now placed under the above genus because they lack setæ on the cubitus and media.

Face short; palpi 4-jointed, the first very short and not always differentiated from the second; antennæ 2 plus 14 jointed; 3 ocelli, the laterals remote from the eye margin. Thorax moderately arched. Legs slender, tarsal claws not toothed. Wings microscopically setulose, not hairy; cubitus and media with no setæ.

Type: Sciara coprophila Lintner.

TABLE OF NORTH AMERICAN SPECIES OF THE REVISED GENUS Sciara AND OF Neosciara.

a. Genus Sciara. Costa, radius, media except sometimes the petiole, and cubitus of the wings distinctly though sparsely setose.

*b. Large southern species, $6 \mathrm{~mm}$. or more in length; males undescribed,

bb. Medium or small species. cingulata Rubsaamen

c. $R_{1}$ ends noticeably proximad of the fork of $M$.

*d. Petiole of cubitus one-eighth as long as the basal section of M. (Fig. 219); clasper (Fig. 100); N. Y ......................... vicina Joh.

dd. Petiole of cubitus scant half or more than half as long as the basal section of $\mathrm{M}$.

e. Clasper with at least one stout apical spine.

f. Clasper with a single stout spine; costa produced two-thirds the distance from the tip of $R_{s}$ to $M_{1}$ (Fig. 220); clasper (Fig. 101); Cal .

ff. Clasper (Fig. 1) with several stout apical spines and one more prominent subapical spine; costa produced less than two-thirds the distance from the tip of $\mathrm{R}_{\mathrm{s}}$ to $\mathrm{M}_{1}$, (Fig. 32)...1. forceps $\mathrm{n}$. $\mathrm{sp}$.

ee. Clasper with no stout apical spines.

f. The perpendicular distance from the crest of the arc of $\mathrm{M}_{1}$ to that of $R_{\mathrm{s}}$ greater than the perpendicular distance from the tip of $R_{\mathrm{s}}$ to $M_{1}$ (Fig. 33). Petiole of cubitus longer than the base of $M$. Clasper (Fig. 2) ..................... multisetifera n. sp.

* This table is based largely on male characters, only a few well defined species represented by females alone are included; cingulata is placed under both genera since it is not certain whether the cubitus and media have setæ or not. By wing length is meant the distance from the humeral cross vein to the tip of the wing, measured parallel to the longitudinal axis.

The figures and descriptions of those species not designated as new may be found in the Maine Agr. Exp. Sta. Bull. 200, part IV.

All the types and some paratypes of the new species are to be found in the Cornell University collection. 
ff. The perpendicular distance from the crest of the arc of $M_{1}$ to that of $R_{s}$ less than the perpendicular distance from the tip of $R_{s}$ to $M_{1}$.

g. Petiole of cubitus less than three-fourths the length of the base of media; costa produced at least two-thirds the distance between the tips of $R_{s}$ and $M_{1}$ (Fig. 34). Clasper (Fig. 3),

3. cylindrica $\mathrm{n} . \mathrm{sp}$.

gg. Petiole of cubitus more than three-fourths the length of the base of media; costa not produced two-thirds the distance between the tips of $R_{s}$ and $M_{1}$.

h. Wing wide at base, subcosta exceptionally long and almost reaching the costa, base of $\mathrm{R}_{\mathbf{s}}$ evanescent; setæ or slender spines at tip of clasper larger than the setæ along the inner margin; tip of $\mathrm{R}_{\mathrm{s}}$ ends proximad of tip of $\mathrm{M}_{2}$ (Fig. 35). Clasper (Fig. 4). (See figures in this paper)......4. congregata Joh.

hh. Wing normal at base; subcosta normal; base of $\mathrm{R}_{\mathbf{B}}$ distinct; setæ at apex of clasper not larger than those along its inner margin; tip of $R_{s}$ ends slightly distad of tip of $M_{2}$ (Fig. 36). Clasper (Fig. 5) ................... psittacus n. sp.

cc. $R_{1}$ ends about opposite or distad of the base of the fork of $\mathrm{M}$; species $2.5 \mathrm{~mm}$ or more in length.

d. Petiole of cubitus over one-half as long as the basal section of $M$.

e. $\mathrm{R}_{1}$ ends about opposite the forking of $\mathrm{M}$. (Fig. 221).... futilis Joh. ee. $R_{1}$ ends distad of the forking of M. (Fig. 266)...........abdita Joh.

dd. Petiole of cubitus less than one-fourth as long as the basal section of $\mathbf{M}$.

e. Humeri, pleura in part and hypopygium (Fig. 103) more or less yellow; knob of halteres dark.

ee. Thorax and abdomen black.

f. Clasper with two distinct clusters of stout spines, one apical, the other subapical (Fig. 104)

ff. Clasper of different structure.

g. Halteres and coxæ yellow.

h. Clasper with a few, about 5 subequal stout spines along the inner margin (Fig. 139)...........................

hh. Clasper (Fig. 6) with many, over 12 subequal, rather slender spines along the inner margin. Wing (Fig. 37),

6. habilis var.

gg. Knobs of halteres and coxæ fuscous. Wing (Fig. 38). Clasper (Fig. 7)

aa. Genus Neosciara. Media and cubitus without setæ.

7. globosa n. sp.

b. Large southern species, $6 \mathrm{~mm}$. or more in length; males undescribed.

c. $R_{1}$ ends distad of the base of the fork of M; wings blackish (Fig. 218),

*cc. $\mathrm{R}_{1}$ ends about opposite the base of the fork of $\mathrm{M}$. picea Rübsaamen

bb. Medium or small species.

c. $R_{1}$ ends distad, or opposite (not more than one-tenth of wing length proximad) of the base of the fork of $M$, and base of $R_{s}$ at or proximad of a point midway between the humeral crossvein and the tip of $R_{1}$.

d. Thorax yellowish to rufous, coxæ and femora dull yellow.

e. Claspers large, triangular, no terminal stout spine. Petiole of cubitus less than one-half as long as the basal section of media (Fig. 111),

ee. Clasper (Fig. 8) cylindrical, with one stout apical spine. Petiole of cubitus more than one-half as long as the basal section of media.

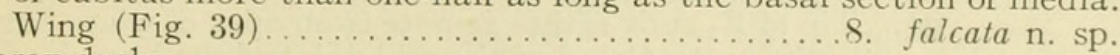

dd. Thorax dusky.

e. $\mathrm{R}_{\mathbf{s}}$ ends proximad of the tip of $\mathrm{M}_{2}$; halteres dark.

f. Clasper with 2 median lobes (Fig. 109); costa produced about onehalf way from tip of $\mathrm{R}_{\mathrm{s}}$ to $\mathrm{M}_{1} \ldots \ldots \ldots$..... tridentata Rubsaamen

ff. Clasper without median lobes; costa produced distinctly over half way from tip of $R_{s}$ to $M_{1}$.

g. Clasper with 2 or 3 stout apical spines. 
h. Hypopygium with 2 clusters of setæ, 1 on each side of the midventral line, no long slender seta on the inner margin of the clasper (Fig. 9). Costa produced not over two-thirds the way from the tip of $\mathrm{R}_{\mathrm{s}}$ to the tip of $\mathrm{M}_{1}$ (Fig. 40)..9. fochi $\mathrm{n}$. $\mathrm{sp}$.

hh. Hypopygium with no cluster of setæ on each side of the midventral line, at least one long slender seta on the inner margin of the clasper (Fig. 10). Costa produced over two-thirds the distance from the tip of $R_{s}$ to the tip of $M_{1}$ (Fig. 41)... 10. joffrei n. sp.
munda Joh. ee. $\mathrm{R}_{\mathrm{s}}$ ends opposite or distad of the tip of $\mathrm{M}_{2}$.

f. $\mathrm{R}_{1}$ ends distad of the forking of $\mathrm{M}$; halteres dark.

g. Clasper with a mesal process. $R_{s}$ ends noticeably distad of the tip of $\mathrm{M}_{2}$.

h. Mesal process of claspers robust (Fig. $106 \mathrm{~m}$ ); wing (Fig. 225),

dux Joh.

hh. Mesal process of claspers slender (Fig. $107 \mathrm{~m}$ ); wing (Fig. 226), imitans Joh.

gg. Clasper (Fig. 11) with no mesal process. $R_{s}$ ends about opposite the tip of $\mathrm{M}_{2}$ (Fig. 42) ............. quadrispinosa n. sp.

ff. $R_{1}$ ends about opposite the forking of $\ddot{M}$.

g. Apical tooth of clasper placed near the mesal margin of the apex (Fig. 115); Species under $2.5 \mathrm{~mm}$. Halteres dusky yellow,

varians Joh.

gg. Apical tooth of clasper placed at apex (Fig. 108) or tooth wanting. (Fig. 123).

h. Halteres blackish; hind coxæ and legs brownish; claspers without apical tooth (Fig. 123); wing (Fig. 232).

jucunda Joh.

hh. Halteres and coxæ yellowish; clasper with distinct apical tooth (Fig. 108).

i. Halteres and coxæ yellowish. Clasper with no subapical spines.

j. Petiole of cubitus about .6 as long as the basal section of M. (Fig. 227) ..................... prolifica Felt.

jj. Petiole of cubitus over .8 as long as the basal section of $\mathbf{M}$. k. Wing veins heavily shaded (Fig. 228).... prolifica var. a.

kk. Wing veins not shaded................ prolifica var. b.

ii. Halteres fuscous. Coxæ dull brown. Clasper (Fig. 18 a, b) with several subapical stout spines. Wing (Fig. 49).

18. conglomerata $\mathrm{n}$. $\mathrm{sp}$.

cc. $R_{1}$ ends at least one-sixteenth of the wing length proximad of the forking of $M$; the base of $R_{s}$ is distad of the mid point between the humeral cross vein and the tips of $R_{1}$.

d. Fulvous mesonotum, abdomen more dusky; or reddish species.

e. Dusky red species, female $4 \mathrm{~mm}$. long, halteres white; male not described......................................... Kieffer

ee. Fulvous mesonotum, abdomen more dusky, length $2 \mathrm{~mm}$. or less.

f. Clasper without strong spines at apex.

g. Tip of $R_{s}$ ends far remote from apex of wing at a point on the costa about opposite the mid point of branch $M_{1}$ (Fig. 229). Clasper with several rather slender spines on the inner margin proximad of the mid point (Fig. 110).............mellea Joh.

gg. Tip of $R_{s}$ ends rather remote from apex of wing, but at a point on the costa distad of the mid point of the branch of $\mathrm{M}_{1}$. Clasper (Fig. 12) with about 5 stout spines and one longer, more slender spine at the middle of the inner margin. Wing (Fig. 43).

ff. Clasper with one or more apical spines.

12. luteola $\mathrm{n}$. sp.

g. $M_{1}$ less than .8 as long as the petiole of the media tritici Coquillett gg. $M_{1}$ at least .9 as long as the petiole of the media. 
h. Hypopygium with a median ventral lobe at base finely setose, clasper with single stout apical spine. (Fig. 13, a, b). Wing

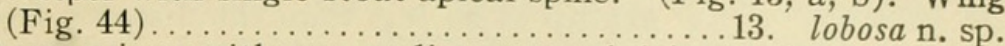

hh. Hypopygium with no median ventral lobe at base, clasper with more than one apical spine (Fig. 265).

dd. Black or fuscous species.

ocellaris Comstock

e. Clasper with a mesal articulated process (Fig. 112); $\mathrm{R}_{\mathbf{8}}$ ends far remote from apex of wing. (Fig. 230) ............. hastata Joh.

ee. Clasper without mesal articulated process.

f. Hypopygium near its base with one or two patches of setæ on or by the side of the median ventral line.

g. Hypopygium with one patch of setæ on the median ventral line near its base.

h. Clasper (Fig. 14, a, b) concave at apex, with at least two stout long spines, and over eight smaller spines on the margin of the concavity. Wing (Fig. 45)....... 14. petaini n. sp.

hh. Clasper of different form and structure.

i. Clasper with a terminal tooth.

j. Clasper blunt at apex. (Fig. 15, a, b). Wing (Fig. 46).

jj. Clasper tapering at apex and with several prominent subapical spines.

k. Hypopygium with no more than 10 setæ on the basal median ventral line.

1. Costa extends about half the distance between the tips of $\mathrm{R}_{\mathrm{s}}$ and $\mathrm{M}_{1}$

m. Wing of normal proportions (Fig. 47). Median ventral lobe of hypopygium distinct (Fig. 16, a, b). 16. trifolii n. sp.

mm. Wing narrow (Fig. 240). Median ventral lobe of hypopygium indistinct. Clasper (Fig. 120).

sativæ Joh.

11. Costa extends about two-thirds the distance between the tips of $\mathrm{R}_{\mathrm{s}}$ and $\mathrm{M}_{1}$. (Fig. 117a)..pauciseta Felt.

kk. Hypopygium with more than 25 setæ on the basal median ventral line.

1. Abdomen variable dark ochreous, palpi yellow, anterior veins dark ochreous...............multiseta Felt.

11. Abdomen variable dark brown, palpi brown, anterior veins nearly black.................. agraria Felt.

ii. Clasper without a terminal tooth (Fig. 123); the hypopygium with the setæ of the ventral median patch arranged in a transverse line (Fig. 123a). Halteres black. jucunda Joh.

gg. Hypopygium with 2 patches of setæ, one on each side of the median ventral line.

h. Clasper with subapical stout spines, the proximal one longest.

i. Clasper (Fig. 17 a, b) with 6 or more subapical stout spines, the most proximal one being longer than the others. Costa produced less than one-half the distance between the tips of $\mathrm{R}_{\mathrm{s}}$ and $\mathrm{M}_{1}$ (Fig. 48)............. polychaeta n. $\mathrm{np}$.

ii. Claspers (Fig. 18, a, b) with 3 or 4 subapical stout spines. Costa produced at least one-half the distance between the tips of $R_{s}$ and $M_{1}$ (Fig. 49).......... conglomerata $\mathrm{n}$. $\mathrm{sp}$.

hh. Clasper (Fig. 128) with no subapical stout spines. Costa produced over one-half the distance between the tips of $\mathrm{R}_{\mathbf{8}}$ and $\mathrm{M}_{1}$. Cu petiole at least half length of base of $\mathrm{M}$

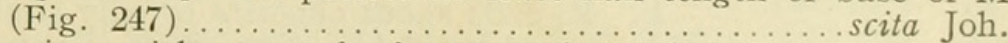

ff. Hypopygium without a tuft of setæ on the median ventral line near the base, or if feeble tuft is present then petiole of cubitus is not under . 6 as long as the basal section of media. 
g. Claspers with 4 or 5 large subequal teeth or spines.

h. Distance from point on the costa opposite the base of $R_{\mathbf{s}}$ to the tip of $R_{1}$ less than the distance from the tip of $R_{1}$ to a point on the costa opposite the forking of the media.

i. Costa extends at least one-half the distance between the tips of $\mathrm{R}_{\mathrm{s}}$ and $\mathrm{M}_{1}$.

j. Clasper (Fig. 119) with one stout spine separate from the other 4 stout spines (Fig. 239)..spinata n. sp. (sp. 24 Joh.)

jj. Clasper with spines equidistant (Fig. 114). Wing (Fig.234). nacta Joh.

ii. Costa extends less than one-half the distance between the tips of $R_{s}$ and $M_{1}$ (Fig. 50). Clasper has no separate stout spine (Fig. 19) .......................... ovata $\mathrm{n}$. $\mathrm{sp}$.

$\mathrm{hh}$. Distance from point on the costa opposite the base of $\mathrm{R}_{\mathrm{s}}$ to the tip of $R_{1}$ greater than the distance from the tip of $R_{1}$ to a point on the costa opposite the forking of the media. Wing (Fig. 233). Clasper (Fig. 113)............. mutua Joh.

\section{gg. Claspers of different structure.}

h. Petiole of cubitus short, less than one-half as long as basal section of $M$.

i. $\mathrm{R}_{\mathrm{s}}$ ends distad of $\mathrm{M}_{2}$; costa produced about one-half of distance from $R_{s}$ to $M_{1}$. Mesonotum highly polished.

j. Halteres and coxæ bright yellow.(=nigricans Joh).

ji. Halteres fuscous, (Figs, 217, 260) johannseni End.

ii. Costa produced over one-half distance from $\mathrm{R}_{\mathrm{s}}$ to $\mathrm{M}_{1}$; if not, then $R_{\mathrm{s}}$ ends proximad of tip of $\mathrm{M}_{2}$.

j. Clasper with 3 stout or several not stout apical teeth or spines.

k. Clasper with about 3 stout apical spines.

1. Distance from a point on the costa opposite the base of $R_{s}$ to the tip of $R_{1}$ much less than the distance from the tip of $R_{1}$ to a point on the costa opposite the forking of media.

$m$. $R_{s}$ ends on the costa opposite a point on $M_{1}$ proximad of the midpoint of $M_{1}$.

n. Costa extends less than one-half the distance between the tips of $R_{s}$ and $M_{1}$ (Fig. 267).

cucumeris Joh.

nn. Costa extends a little more than one-half the distance between the tips of $R_{s}$ and $M_{1}$ (Fig. 241). fatigans Joh.

$\mathrm{mm}$. $\mathrm{R}_{\mathrm{s}}$ ends on the costa opposite a point on $\mathrm{M}_{1}$ slightly distad of the midpoint of $M_{1}$. Costa extends less than one-half the distance between the tips of $\mathrm{R}_{\mathrm{s}}$ and $\mathrm{M}_{1}$ (Fig. 51). Clasper (Fig. 20).

20. trifurca n. sp.

11. Distance from a point on the costa opposite the base of $R_{s}$ to the tip of $R_{1}$ slightly greater than the distance from the tip of $R_{1}$ to a point on the costa opposite the forking of media (Fig. 52). Clasper (Fig. 21).

21. pilata $\mathrm{n}$. $\mathrm{sp}$.

kk. Clasper with more than three spines all of which are slender and not conspicuously distinguished from the setæ of the clasper...................... copophila Lint.

jj. Clasper without any or with only a single prominent apical or subapical tooth.

k. $R_{1}$ ends about opposite or only slightly proximad of the forking of M. (Fig. 255). Knob of halteres and coxæ brownish. Clasper (Fig. 115)....... varians Joh. var. c.

kk. $R_{1}$ ends considerably proximad of the forking of $M$. 
1. Clasper globular or subglobular.

$\mathrm{m}$. Thorax subopaque, not very shiny.

n. Clasper with a single stout spine, subapical in position. longispina n. sp. (Fig. 116).

nn. Clasper with no stout spines (Fig. 27 Joh.) (Fig. 22). Wing

$\mathrm{mm}$. Thorax very shiny. Clasper subglobicia n. sp.

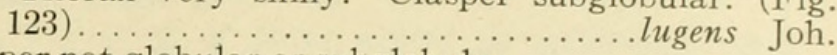

11. Clasper not globular or subglobular.

m. Clasper with a stout apical or stout subapical spine.

n. Clasper with several subapical, slender, rather long spines (Fig. 131). $\mathrm{R}_{\mathbf{s}}$ ends about opposite the tip of $\mathrm{M}_{2}$ (Fig. 250). Mesonotum highly polished ..........................

nn. Clasper with no subapical, slender, long spines. $\mathrm{R}_{\mathbf{8}}$ ends considerably proximad of the tip of $\mathrm{M}_{2}$ (Fig. 54).

o. Stout spine subapical (Fig. 67). (See plate, this key). Media forks distad of tip of $\mathrm{Cu}_{2}$; $\mathrm{R}_{\mathrm{s}}$ almost straight, only slightly curved at tip and usually distant from $\mathrm{M}_{1}$....hartii Joh. oo. Stout spine apical (Fig. 23).

p. Cu petiole less than half the length of the base of M. Distance from point on costa opposite the base of $R_{s}$ to the tip of $R_{1}$ greater than the distance from the tip of $R_{1}$ to a point on costa opposite the forking of $\mathbf{M}$. Branches of $M$ considerably diverging. Wing (Fig. 54). Clasper (Fig. 23).

23. penna. n. sp.

pp. Cu petiole at least half the length of base of M. Distance from point on costa opposite the base of $R_{s}$ to the tip of $R_{1}$ not greater than distance from tip of $R_{1}$ to a point on costa opposite the forking of $\mathrm{M}$. Branches of $M$ only slightly diverging. Wing (Fig. 56). Clasper (Fig. 25) ...25. hamata n. sp.

mm. Clasper with no stout apical or subapical spine. Halteres luteous. Wing (Fig. 61). Clasper (Fig. 30). 30. perfecta n. sp.

hh. Petiole of cubitus at least half as long as the basal section of $\mathrm{M}$. i. $R_{s}$ ends proximad of .85 of the length of the wing.

j. Clasper with 2 strong apical spines (Fig. 118). Wing veins strongly defined (Fig. 238). Thorax shining black.

jj. Clasper and wing of different structure.

parilis Joh.

k. Costa produced less than two-thirds of distance from $\mathrm{R}_{\mathrm{s}}$ to $\mathrm{M}_{1}$.

1. Clasper with one or more stout apical spines.

m. Wing narrow (Fig. 240). Clasper with one stout apical spine; hypopygium with an indistinct basal cluster of setæ on the mid-ventral line (Fig. 120).

mm. Wing wider (Fig. 267). Clasper with 3 ative Joh. spines; hypopygium with no trace of basal cluster of setæ on the mid-ventral line (Fig. 261).

11. Clasper with no stout apical spines, cucumeris Joh. slender subapical seta. (Fig. 24). Wing (Fig. 55).

24. pollicis $\mathrm{n}$. sp. 
kk. Costa produced over two-thirds from $\mathrm{R}_{\mathrm{s}}$ to $\mathrm{M} 1$.

1. Clasper with two apical teeth (Fig. 121). Petiole of cubitus about three-fourths as long as basal section of M. Hind tarsus shorter than the tibia.

11. Clasper with a median process (Fig. 122). $\begin{aligned} & \text { sp.-33 Joh. } \\ & \text { Petiole of }\end{aligned}$ the cubitus about half as long as the basal section of M. (Fig. 242). Hind tarsus and tibia subequal.

ii. $\mathrm{R}_{\mathrm{s}}$ ends distad of .85 of wing length. neglecta Joh.

j. Clasper with one prominent terminal or subterminal spine or tooth, or if several teeth are present, one is conspicuously larger than the others.

k. Costa produced about one-half way from $R_{\mathrm{s}}$ to $\mathrm{M}_{1}$.

1. Halteres bright yellow. Claspers (Fig. 125). Wing (Fig. 243). $\quad R_{\mathrm{s}}$ ends distad of the tip of $\mathrm{M}_{2}$.

(=nigricans Joh.) johannseni End.

11. Halteres fuscous. $R_{s}$ ends opposite or proximad of the tip of $\mathrm{M}_{2}$.

m. $\mathrm{R}_{\mathrm{s}}$ ends about opposite the tip of $\mathrm{M}_{2}$; Wing (Fig. 217). Mesonotum highly polished........... actuosa Joh.

$\mathrm{mm}$. $\mathrm{R}_{\mathrm{s}}$ ends considerably proximad of the tip of $\mathrm{M}_{2}$ (Fig. 56). Mesonotum shiny. Clasper (Fig. 25).

kk. Costa produced over half way from $R_{8}$ to $M_{1}$.

25. hamata n. sp.

1. Costa produced over three-fourths way from $R_{s}$ to $M_{1}$

(Fig. 244). Halteres yellow. Claspers (Fig. 126).

11. Costa produced less than .7 from $\mathrm{R}_{\mathrm{s}}$ to $\mathrm{M}_{1}$.

S. $s p .37$ Joh.

m. $R_{1}$ ends over one-fifth of wing length proximad of the forking of the media (Fig. 245). Halteres dark. Clasper (Fig. 127)............dolens Joh.

$\mathrm{mm} . \mathrm{R}_{1}$ ends considerably less than one-fifth of wing length proximad of the forking of $M$.

$n$. Apex or near the apex of clasper with a number of spines of which one is somewhat larger or stouter than the others.

o. Halteres yellow. Clasper (Fig. 132).

oo. Halteres dark. Clasper (Fig. 140).

diluta Joh.

diluta Joh. var. a

nn. Spine of apex of clasper distinctly differentiated from the apical setæ or from those near the apex.

o. Halteres yellow. Clasper with no subapical spines differentiated from the setæ of the clasper.

p. Costa produced less than five-eighths of the distance from $R_{s}$ to $M_{1}$

q. Hind tibia a little shorter than the tarsus. Wing (Fig. 246)............ varians Joh.

qq. Hind tibia and tarsus subequal in length. varians, var. a.

pp. Costa produced over two-thirds of distance from $R_{s}$ to $M_{1} \ldots \ldots \ldots \ldots$ varians, var. $b$. oo. Knobs of halteres fuscous.

p. Clasper (Fig. 26) with several long slender subapical spines, a little longer than the stout apical spine. The distance from the tip of $R_{1}$ to the point on the costa opposite the forking of $\mathrm{M}$ is greater than the distance between the tips of $M_{1}$ and $M_{2}$ (Fig. 57).

26. felti n. sp. 
pp. Clasper (Fig. 27) with no long subapical spines. The distance between the tip of $\mathrm{R}_{1}$ and the point on the costa opposite the forking of $M$ is not greater than the distance between the tips of $\mathrm{M}_{1}$ and $\mathrm{M}_{2}$. Wing. (Fig. 58)...27. macroptera n. sp.

jj. Clasper with two or more prominent apical teeth, spines, or with strong setæ.

k. Clasper with two or three apical or subapical spines. Knobs of halteres black or brown.

1. Black species $3 \mathrm{~mm}$. in length, with blackish legś. Clasper subglobose (Fig. 128)...........scita Joh.

11. Smaller species with fuscous yellowish legs. Claspers more slender.

m. Spines of clasper unusually short (Fig. 129). The distance from the tip of $\mathrm{R}_{1}$ to the point on the costa opposite the forking of $\mathrm{M}$ is greater than the distance between the tips of $M_{1}$ and $M_{2}$.

fumida Joh.

$\mathrm{mm}$. Spines of clasper not unusually short. The distance from the tip of $R_{1}$ to the point on the costa opposite the forking of $\mathrm{M}$ is less than the distance between the tips of $\mathrm{M}_{1}$ and $\mathrm{M}_{2}$.

n. Clasper (Fig. 130) with three or four slender subequal spines, two or three near the apex, the other near the apical third, all on the inner margin. Petiole of cubitus about as long as or longer than the base of media (Fig. 249).

trivialis Joh.

nn. Clasper (Fig. 28) with three rather stout subequal spines, all clustered at the apex. Petiole of cubitus much shorter than the base of media (Fig. 59) .............28. subtrivialis n. $\mathrm{sp}$.

kk. Clasper with five or more apical and subapical setæ or spines.

1. Apex of clasper with six or eight spines, one of which is set at an angle to the others. (Fig. 137). Halteres yellow. Wing (Fig. 252)........... impatiens Joh.

11. Apex of clasper with spines or setæ subequal in size and distance from each other.

m. Clasper with about six stout conspicuous subequal spines (Fig. 29). Wing (Fig. 60).

29. sexdentata $\mathrm{n} . \mathrm{sp}$.

$\mathrm{mm}$. Clasper with no conspicuous or stout spines.

n. $\mathrm{M}_{2}$ distinctly shorter than length of petiole of media. Coxæ yellowish. (Fig. 133).

coprophila Lint.

nn. $\mathrm{M}_{2}$ about equal in length to the petiole of media. Coxæ brown or black. Wing (Fig. 62). Clasper (Fig. 31). (Compare caldaria Lint.)

caldaria var. 


\section{SCIARA.}

\section{Sciara forceps n. sp.}

Male: Length, $1.6 \mathrm{~mm}$. Head black, shiny; palpi and scape of antennæ luteous, antennæ broken. Thorax; mesonotum shiny, black; humeri and pleura of prothorax luteous; metanotum and pleuræ of meso and metathorax fuscous. Abdomen dark fuscous with posterior third of the abdominal segments and venter luteous; hypopygium light brown; clasper (Fig. 1) with several stout apical spines, one slightly stouter than the rest, and one very prominent large, subapical spine, giving the clasper a bifurcated appearance. Coxæ and femora luteous, trochanters black, tibiæ and tarsi fuscous. Wings (Fig. 32) hyaline; media and cubitus setose; base of $\mathrm{R}_{\mathrm{s}}$ noticeably distad of the midpoint between the humeral cross vein and the tip of $R_{1} ; R_{1}$ ends noticeably proximad of the forking of media; petiole of cubitus distinctly longer than the base of media; costa extends over half the distance between the tips of $R_{s}$ and $M_{1} ; R_{s}$ ends distad of .85 the length of the wing and slightly proximad of the tip of $\mathrm{M}_{2}$. Halteres; pedicel luteous, knobs darker.

This species is closely related to dives, but may be distinguished from the latter by the characters of the clasper, the color of the body and the fact that the petiole of the media is setose.

Described from 1 male collected May 3, 4, 1916, at Palatka, Florida, by J. C. Bradley. Type No. 207.

\section{Sciara multisetifera n. sp.}

Male: Length, $2.8 \mathrm{~mm}$. Head piceous to black; antennæ of dried specimen half as long as body, piceous to black. Thorax, abdomen piceous to black, the posterior margins of the second, third and fourth abdominal segments grayish. Angles of humeri dull luteous. Appendages, including palpi, halteres, legs and hypopygium fuscous. Hypopygium; clasper (Fig. 2) with many setæ shorter than the numerous slender spines along the inner margin. Wings (Fig. 33) smoky brown; media branches setose; base of $\mathrm{R}_{\mathrm{s}}$ noticeably distad of the midpoint between the humeral cross vein and the tip of $R_{1} ; R_{1}$ ends proximad of the forking of media; petiole of cubitus distinctly longer than the base of media; costa extends about half the distance between the tips of $\mathrm{R}_{\mathrm{s}}$ and $\mathrm{M}_{1} ; \mathrm{R}_{\mathrm{s}}$ ends far distad of .85 the length of the wing and distad of the tip of $\mathrm{M}_{2}$.

This species differs from cylindrica, its near relative, by having many more setæ on the clasper, all of which are shorter than those on the inner margin.

Described from 3 males, collected in South Arizona, Aug., 1902, by F. H. Snow. Type No. 208. Two allotypes. 


\section{Sciara cylindrica $n$. sp.}

Male: Length, $1.5 \mathrm{~mm}$. Head shiny black; antennæ almost black; palpi almost black. Thorax shiny black. Abdomen and hypopygium almost black. Hypopygium; clasper (Fig. 3) as wide at the apex as at the middle, setæ longer than the about 8 rather slender spines of the inner margin. Coxæ dull luteous, femora, tibiæ and tarsi fuscous. Wings (Fig. 34) hyaline, media and cubitus setose; base of $\mathrm{R}_{\mathrm{s}}$ slightly distad of the midpoint between the humeral cross vein and the tip of $R_{1} ; R_{1}$ ends proximad of the forking of media; petiole of cubitus evanescent, apparently less than half the length of the base of media; costa extends about two-thirds the distance between the tips of $R_{s}$ and $\mathrm{M}_{1} ; \mathrm{R}_{\mathrm{s}}$ ends distad of .85 the length of the wing, and slightly proximad of the tip of $\mathrm{M}_{2}$. Halteres luteous with dark knob.

This species may be distinguished from its near relatives, congregata, psittacus, and cylindrica by the form of the clasper and by the petiole of cubitus being shorter than the base of media.

Described from 1 male, collected May 15-19, 1907, at Felton, St. Cruz Mts., Cal., by J. C. Bradley, Type No. 209.

\section{Sciara congregata Joh.}

Psyche. Vol. XXI. June 1914, No. 3, pp. 93, 95.

Male: Length, $2 \mathrm{~mm}$. Head black; antennæ fuscous, short (about two-thirds as long as wing from humeral cross vein), joints not twice as long as wide; palpi fuscous. Mesonotum subshining blackish; scutellum, metanotum and pleura subopaque, brownish black. Abdomen subopaque, brownish black. Hypopygium brownish black; no median ventral setiferous lobe; claspers resemble those of jucunda, but apical setæ are stouter. Legs brown, the tarsi darker; hind tibia about as long as the petiole of the media of the wing; apical third of tibiæ slightly broadened; hind tarsus about .8 as long as the tiba, hind metatarsus slightly over .7 as long as the following 4 joints. Wings (Fig. 35 ) smoky; veins dark brown, forks of media and apical part of forks of cubitus setose; $\mathrm{R}_{1}$ ends one-third as far proximad of the forking of media as the tip of $R_{s}$ is distad of this point; basal section of $R_{s}$ very faint but is evidently distad of the midpoint between the humeral cross vein and the tip of $\mathrm{R}_{1}$; petiole of cubitus slightly longer than the basal section of $\mathrm{M}$; media petiole is indistinct; costa produced half of the distance between the tips of $\mathrm{R}_{\mathrm{s}}$ and $\mathrm{M}_{1} ; \mathrm{R}_{\mathrm{s}}$ ends distad of .85 the length of the wing and slightly proximad of the tip of $\mathrm{M}_{2}$. Halteres dark.

Female: Length, $2.5 \mathrm{~mm}$. Like the male in coloring and structure, differing in having slightly shorter antennæ, these being less than one-half as long as the wing, with intermediate joints but little longer than wide; the basal section of $\mathrm{R}_{\mathrm{s}}$ and the petiole of media a little more distinct. The lamellæ of the ovipositor are only slightly longer than wide.

Type in Dr. Johannsen's collection, Cornell University. Paratypes in the collection of the Arkansas Exp. Station. 


\section{Sciara psittacus n. sp.}

Male: Length, $1.9 \mathrm{~mm}$. Head fuscous; antennæ fuscous, scape luteous; palpi fuscous. Thorax fulvous. Abdomen fuscous with posterior margin of each segment and the whole of the venter luteous. Hypopygium fulvous, clasper (Fig. 5) distinctly narrower at apex than the middle, with the comparatively few setæ on the surface longer than the numerous slender spines along the inner margin. Coxæ and femora luteous, trochanters black; tibiæ and tarsi fuscous. Wings (Fig. 36) hyaline; media and cubitus setose; the petiole of media evanescent or very faint; base of $R_{s}$ considerably distad of the midpoint between the humeral cross vein and the tip of $R_{1} ; R_{1}$ ends considerably proximad of the forking of media; petiole of cubitus about as long as the base of media, costa extends about half the distance between the tips of $R_{s}$ and $\mathrm{M}_{1} ; \mathrm{R}_{\mathrm{s}}$ ends distad of .85 the length of the wing and about opposite the tip of $\mathrm{M}_{2}$. Halteres luteous.

Described from 1 male collected in Maine, Aug. 21, 1913, by C. P. Alexander. Type No. 210.

\section{Sciara habilis var.}

Male: Length, $2.4 \mathrm{~mm}$. Head black; antennæ fuscous with dull fulvous scape; palpi fuscous. Thorax subshining, black, covered with a fine, whitish powder. Abdomen and hypopygium almost black. Hypopygium; clasper (Fig. 6) narrower at apex than middle, the setæ as long or longer than the numerous rather short spines along the inner margin. Coxæ and femora luteous; trochanters black, tibiæ and tarsi fuscous. Wings (Fig. 37) hyaline; media and cubitus setose; base of $R_{s}$ about at the midpoint between the humeral cross vein and the tip of $\mathrm{R}_{1} ; \mathrm{R}_{1}$ ends slightly distad of the forking of media; petiole of cubitus less than one-fourth the length of the base of media; costa extends two-thirds the distance between the tips of $\mathrm{R}_{\mathrm{s}}$ and $\mathrm{M}_{1} ; \mathrm{R}_{\mathrm{s}}$ ends distad of .85 the length of the wing and very slightly proximad of the tip of $\mathrm{M}_{2}$. Halteres luteous.

This variety differs from Sciara habilis, by having more subequal spines along the inner margin, and by the fact that habilis is larger.

Described from one male, collected at Clayton, Ga., May 18-26, 1911. Type No. 211.

\section{Sciara globosa n. sp.}

Male: Length, $3.2 \mathrm{~mm}$. Head black, shiny; antennæ fuscous with the two basal segments fulvous; palpi fuscous. Thorax shiny, dark fuscous with angles of humeri fulvous. Abdomen dark fuscous, with posterior third of each segment black. Hypopygium dark fuscous; clasper (Fig. 7) subglobose, with about 6 stout subapical spines surrounded by short setæ. Coxæ, femora, tibiæ and tarsi fuscous, trochanters black. Wings (Fig. 38) smoky brown; media and cubitus 
setose; base of $R_{s}$ about at the mid-point between the humeral cross vein and the tip of $R_{1} ; R_{1}$ ends distad of the forking of media; petiole of cubitus less than one-fourth the length of the base of media; costa extends about two-thirds the distance between the tips of $R_{s}$ and $M_{1}$; $\mathrm{R}_{\mathrm{s}}$ ends distad of .85 the length of the wing and slightly proximad of the tip of $\mathrm{M}_{2}$. Halteres fuscous.

This species is similar to both habilis and serrosa, but differs from both by having a subglobose clasper, and by having dark coxæ and halteres.

Described from 1 male, collected at Muir Woods, Cal., Aug. 30, 1908, by J. C. Bradley, Type No. 212.

\section{NEOSCIARA.}

(New genus.)

\section{Neosciara falcata n. sp.}

Male: Length, $2.3 \mathrm{~mm}$. Head black; antennæ: flaggelum black, scape luteous; palpi luteous. Thorax; mesonotum and metanotum fulvous, not shiny, pleura fuscous. Abdomen fuscous. Hypopygium brown, with a basal median ventral lobe (Fig. 8, b) on which are about 14 prominent spines arranged in 2 rather indistinct rows; clasper (Fig. 8, a) with an apical spine and no subapical spines. Legs: coxæ and femora luteous; trochanters, tibiæ and tarsi fuscous. Wings (Fig. 39) hyaline; media and cubitus without setæ; base of $R_{s}$ at the mid-point between the humeral cross vein and the tip of $R_{1} ; R_{1}$ ends slightly (not more than one-tenth the wing length) proximad of the base of the fork of $\mathrm{M}$; petiole of cubitus over half the length of the base of media; costa extends over half the distance between the tips of $R_{s}$ and $\mathrm{M}_{1} ; \mathrm{R}_{\mathrm{s}}$ ends distad of .85 the length of the wing and about opposite the tip of $\mathrm{M}_{2}$. Halteres luteous.

This species is related to fulvicauda but is easily separated from the latter by the structure of the clasper and the longer petiole of cubitus.

Described from one male, collected at Auburndale, Mass., April, 1916. Type No. 213.

\section{Neosciara fochi n. sp.}

Male: Length, $2.5 \mathrm{~mm}$. Head black; antennæ missing; palpi missing. Thorax shiny, black. Abdomen fuscous to black. Hypopygium fuscous, with 2 clusters of prominent spines at the base, one on each side of the mid ventral line (Fig. 9b); clasper (Fig. 9a) with 2 apical stout spines and no subapical spines. Legs fuscous to black. Wings (Fig. 40) smoky; media and cubitus without setæ; base of $\mathrm{R}_{\mathrm{s}}$ at the mid-point between the humeral cross vein and the tip of $R_{1} ; R_{1}$ ends slightly (not more than one-tenth of the wing length) proximad of the forking of $\mathrm{M}$; petiole of cubitus a little longer than the base of media; 
costa extends a little over half the distance between the tips of $R_{s}$ and $\mathrm{M}_{1} ; \mathrm{R}_{\mathrm{s}}$ ends slightly distad of .85 the length of the wing, and noticeably proximad of the tip of $\mathrm{M}_{2}$. Halteres fuscous.

Described from 1 male, collected near Leander, Wyoming, August, by Roy Moodie, at an elevation of 5,000 to 8,000 feet. Type No. 214.

\section{Neosciara joffrei n. sp.}

Male: Length, $2.5 \mathrm{~mm}$. Head dull, black; antennæ fuscous, over half the length of the body; palpi fuscous. Thorax shining, dark fuscous. Hypopygium with no median ventral lobe at base, fuscous; clasper (Fig. 10) conical, with 2 apical subequal stout spines and 1 subapical longer more slender spine. Legs fuscous. Wings (Fig. 41) hyaline; media and cubitus without setæ; base of $R_{s}$ at the midpoint between humerus and the tip of $\mathrm{R}_{1} ; \mathrm{R}_{1}$ ends about opposite the forking of media; petiole of cubitus over half the length of the base of media; costa extends over two-thirds the distance between the tips of $R_{s}$ and $\mathrm{M}_{1} ; \mathrm{R}_{\mathrm{s}}$ ends slightly distad of .85 the length of the wing and proximad of the tip of $\mathrm{M}_{2}$. Halteres fuscous.

This species is similar to fochi, but differs in structure and shape of the clasper, the shorter petiole of cubitus, and the longer costa.

Described from one male, collected at North Mt., Pa., June 7. Type No. 215.

\section{Neosciara quadrispinosa n. sp.}

Male: Length, $2.6 \mathrm{~mm}$. Head shiny, black; antennæ piceous, over half the length of the body; palpi piceous. Thorax shiny, piceous to black. Abdomen piceous, the anterior half of the intermediate segments brown. Hypopygium brown, with no median ventral lobe at the base; clasper (Fig. 11) circular, with 4 long conspicuous stout spines at the apex, no subapical spines. Coxæ, femora and tibiæ luteous, tarsi fuscous. Wings (Fig. 42) smoky; media and cubitus without setæ; base of $R_{s}$ at the mid-point between the humeral cross vein and the tip of $R_{1} ; R_{1}$ ends distad of the forking of media; petiole of cubitus less than half the length of the base of media; costa extends at least two-thirds the distance between the tips of $R_{s}$ and $M_{1} ; R_{s}$ ends distad of .85 the length of the wing and about opposite the tip of $\mathrm{M}_{2}$. Halteres; knobs fuscous, pedicels luteous.

This species differs from $d u x$ and imitans, by having no mesal process on the clasper and by having $R_{s}$ end opposite the tip of $\mathrm{M}_{2}$.

Described from one male collected at North Adams, Mass., March 20. Type No. 216. 


\section{Neosciara luteola n. sp.}

Male: Length, $1.5 \mathrm{~mm}$. Head luteous; antennæ about as long as body, fuscous with scape luteous; segments at least twice as long as wide; palpi luteous. Thorax luteous, shining. Abdomen; dorsum brownish with posterior margin of each segment luteous; venter luteous. Hypopygium luteous, with no median ventral lobe at base; clasper (Fig. 12) with 5 or 6 subapical stout spines and one more slender slightly longer spine, one or two of the most proximad spines points more cephalad than the rest, several very small setæ proximad of the stout spines. Legs luteous, trochanters black. Wings (Fig. 43) hyaline; media and cubitus without setæ; base of $\mathrm{R}_{\mathrm{s}}$ slightly distad of the midpoint between the humeral cross vein and the tip of $R_{1} ; R_{1}$ ends proximad of the forking of media; petiole of cubitus less than half the length of the base of the media; costa extends a little over half the distance between the tips of $R_{s}$ and $M_{1} ; R_{s}$ ends slightly proximad of .85 the length of the wing and proximad of $\mathrm{M}_{2}$. Halteres luteous.

This species is closely related to mellea, but differs in the structure of the clasper and the color of the body.

Described from 2 males collected at Black Rock, Rabun Co., Ga., May 20--23, 1911. Type No. 217, and one paratype.

\section{Neosciara lobosa n. sp.}

Male: Length, $1.5 \mathrm{~mm}$. Head fuscous, not shiny; antennæ with fuscous flagellum and fulvous scape; palpi fulvous. Thorax subshining, fulvous, with a broad median dorsal indistinct fuscous line on the mesonotum. Abdomen fuscous. Hypopygium fuscous, at base with a median ventral lobe covered with minute setæ (Fig. 13b); clasper (Fig. 13a) with a large apical spine and no subapical spines. Legs: coxæ luteous, trochanters fuscous, tibiæ fulvous, tarsi fuscous. Wings (Fig. 44) hyaline; media and cubitus without setæ; base of $R_{s}$ distad of the mid-point between the humerus and the tip of $R_{1} ; R_{1}$ ends distinctly proximad of the forking of media; petiole of cubitus over half the length of the base of media; costa extends a little over half the distance between the tips of $\mathrm{R}_{\mathrm{s}}$ and $\mathrm{M}_{1} ; \mathrm{R}_{\mathrm{s}}$ ends distad of .85 the length of the wing and about opposite the tip of $\mathrm{M}_{2}$. Halteres; knobs fuscous, pedicels luteous.

This species differs from ocellaris by having a median ventral lobe on the hypopygium, and a clasper with only one apical spine.

Described from one male, collected at Carbonate, Columbia River, British Columbia, July 7-12,. 1908, by J. C. Bradley, at an altitude of 2,600 feet. Type No. 218 . 


\section{Neosciara petaini n. sp.}

Male: Length, $1.6 \mathrm{~mm}$. Head black, somewhat shining; antennæ fuscous, about two-thirds the length of the body, segments of flagellum at least twice as long as wide, distal segments more than twice as long as wide; palpi fulvous. Thorax fuscous, somewhat shining. Abdomen fuscous. Hypopygium fuscous, with a cluster of about 10 broad setæ much larger than the surrounding setæ (Fig. 14b) at base on the mid ventral line; clasper (Fig. 14a) concave, at apex, with about 2 very stout spines and at least 10 smaller spines on the margin of the concavity. Legs fulvous, tibiæ and tarsi darker. Wings (Fig. 45) hyaline; media and cubitus with no setæ; base of $R_{s}$ distad of the mid-point between the humeral cross vein and the tip of $R_{1} ; R_{1}$ proximad of the forking of $\mathrm{M}$; petiole of cubitus about as long as the basal section of $\mathrm{M}$; costa extends a little over half the distance between the tips of $R_{s}$ and $\mathrm{M}_{1} ; \mathrm{R}_{\mathrm{s}}$ ends distad of .85 the length of the wing and about opposite the tip of $\mathrm{M}_{2}$. Halteres fuscous.

Described from one male collected in Maryland, May 14, 1909. Type No. 219.

\section{Neosciara grandis n. sp.}

Male: Length, $2 \mathrm{~mm}$. Head black; antennæ and palpi fuscous; antennæ as long as head and thorax. Thorax black, shining; humeri angles fuscous. Abdomen dark fuscous, posterior margins of segments black. Hypopygium (Fig. 15b) dark fuscous, with a patch of about 6 setæ at the base on the median ventral line; clasper (Fig. 15a) blunt at apex with one stout apical spine and no distinct subapical spines. Coxæ and femora fulvous, trochanters black, tibiæ brown, tarsi fuscous. Wings (Fig. 46) hyaline; media and cubitus without setæ; base of $R_{8}$ at about the midpoint between the humeral cross vein and the tip of $R_{1}$; $\mathrm{R}_{1}$ ends proximad of the forking of $\mathrm{M}$; petiole of cubitus not quite half as long as the base of media; costa produced more than half the distance between the tips of $\mathrm{R}_{\mathrm{s}}$ and $\mathrm{M}_{1} ; \mathrm{R}_{\mathrm{s}}$ ends distad of .85 the length of the wing and about opposite the tip of $\mathrm{M}_{2}$. Halteres fulvous.

This species differs from trifolii and pauciseta by having no prominent subapical spines on the clasper.

Described from one male, collected July 13, 1913, on Lost Mount, Cobb Co., Georgia. Type No. 220.

\section{Neosciara trifolii n. sp.}

Male: Length, $1.2 \mathrm{~mm}$. Head black; antennæ fuscous, over twothirds the length of the body. Thorax; mesonotum piceous, shiny, pleuræ fuscous. Abdomen black, intermediate segments with anterior two-thirds fuscous, hairs pale yellow; hypopygium brown, near its base with a small median ventral lobe (Fig. 16b) margined with about 8 setæ; clasper (Fig. 16a) with an apical tooth, and with about 4 stout, 
subequal, scattered spines, and with one proximad, longer, more slender spine along the inner margin. Coxæ and palpi luteous; trochanters black; tibiæ dull yellowish-brown; tarsi fuscous to black; hind tibia and tarsus about equal in length. Wings (Fig. 47) hyaline; veins b-own, rather strongly marked; media and cubitus without setæ; petiole of cubitus slightly less than half the length of the base of media; $\mathrm{R}_{1}$ ends at least one-sixteenth of the wing length proximad of the forking of $\mathrm{M}$; the base of $\mathrm{R}_{\mathrm{s}}$ distad of the mid-point between the humeral cross vein and the tip of $R_{1} ; M_{2}$ ends distad of the termination of $R_{s}$. Twin Falls, Moscow, Idaho.

Female: Length, $1.5 \mathrm{~mm}$. Colored like the male. Moscow, Idaho.

This species is closely related to pauciseta Felt., from which it may be distinguished by the characters of the hypopygium and the more retracted position of the tip of $R_{s}$.

Described from 2 males reared by Professor Burrill, Oct. 27, 1916, and Oct. 3, 1917, and 10 females reared Oct. 27, 1916, from the heads of red clover, Moscow, Idaho. Type No. 221.

\section{Neosciara polychæta n. sp.}

Male: Length, $1.2 \mathrm{~mm}$. Head black; antennæ dark fuscous, over two-thirds the length of the body, scape fulvous, palpi luteous. Thorax black shining. Abdomen fuscous to black; hypopygium fuscous, with 2 patches of setæ at base (Fig. 17b), one on each side of the median ventral line; clasper (Fig. 17) with one large apical spine and about 6 subapical smaller but stout spines, the most proximal one being longer and more slender than the others. Coxæ luteous, trochanters black, femora dull luteous, tibiæ brown, tarsi fuscous. Wings (Fig. 48) hyaline; media and cubitus without setæ; base of $\mathrm{R}_{\mathbf{s}}$ far distad of the mid-point between the tip of $R_{1}$ and the humeral cross vein; $R_{1}$ ends noticeably proximad of the forking of media; petiole of cubitus over half as long as the base of media; costa produced less than half the distance between the tips of $R_{s}$ and $M_{1} ; R_{s}$ ends distad of .85 the wing length, and about opposite the tip of $\mathrm{M}_{2}$. Halteres luteous.

Female: Length, $1.4 \mathrm{~mm}$. Same as male, except the antennæ which have a black scape and are no more than half the length of the body.

Described from 5 males and 1 female collected at Clayton, Georgia, May 18-26, 1911. Type No. 222. Four paratypes and one allotype.

18. Neosciara conglomerata n. sp.

Male: Length, $1.8 \mathrm{~mm}$. Head black; antennæ black, not quite one-half the length of the body. Thorax black, dull, covered with a fine white powder. Abdomen fuscous, the posterior margin of each segment luteous. Hypopygium fuscous, with 2 patches of setæ at the 
base, one on each side of the median ventral line (Fig. 18b); clasper (Fig. 18a) with one large apical spine and about 3 subapical, subequal spines and one subapical long, slender spine proximal to the others. Coxæ dull brown, trochanters fuscous, femora and tibiæ dull fulvous, tarsi almost black. Wing (Fig. 49) hyaline; media and cubitus without setæ; base of $R_{s}$ distad of the mid-point between the tip of $R_{1}$ and the humeral cross vein; $\cdot \mathrm{R}_{1}$ ends proximad of the forking of media; petiole of cubitus is a little over one-half as long as the base of media; costa produced more than one-half the distance between the tips of $R_{s}$ and $M_{1}$; $\mathrm{R}_{\mathrm{s}}$ is about parallel with costa and ends distad of .85 of the wing length and about opposite the termination of $\mathrm{M}_{2}$. Halteres fuscous.

Female: Length, $2.2 \mathrm{~mm}$. Same as male except that in one specimen the venter is dull luteous in color.

Described from 4 males and 4 females collected June 20-27, 1907, at Blue Lake, Humboldt Co., Cal., by J. C. Bradley. Type No. 223. Three paratypes and 4 allotypes.

\section{Neosciara ovata n. sp.}

Male: Length, $1.1 \mathrm{~mm}$. Head black, somewhat shining; antennæ fuscous, at least half the length of the body; palpi fuscous. Thorax fuscous to black, subshining. Abdomen fuscous, intermediate segments dull luteous along the posterior margin. Hypopygium fuscous, no cluster of setæ at base on median ventral line; clasper (Fig. 19) oval with 4 or 5 stout subequal spines near or at the apex. Legs dull fulvous. Wings (Fig. 50) hyaline; media and cubitus without setæ; base of $\mathrm{R}_{\mathrm{s}}$ distad of the mid-point between the humerus and the tip of $R_{1} ; R_{1}$ ends considerably proximad of the forking of $\mathrm{M}$; petiole of cubitus shorter than half the length of the base of $M$; costa extends less than half the distance between the tips of $R_{s}$ and $M_{1} ; R_{s}$ ends slightly proximad of .85 the length of the wing and distinctly proximad of the tip of $\mathrm{M}_{2}$. Halteres fuscous.

This species is closely related to spinata, but differs in the structure of the clasper and the shorter petiole of cubitus.

Described from one male collected at Howser, Selkirk Mts., British Columbia, June 22, 1905, by J. C. Bradley. Type No. 224.

\section{Neosciara trifurca n. sp.}

Male: Length, $1 \mathrm{~mm}$. Head somewhat shining, black; antennæ fuscous, about as long as the body; palpi fuscous. Thorax somewhat shining, fuscous. Abdomen almost black. Hypopygium fuscous with no cluster of setæ at base on the mid-ventral line; clasper (Fig. 20) oval, with about 3 subequal, apical stout spines and no subapical spines, several small setæ along the inner margin. Legs: coxæ, femora and tibiæ dull fulvous, trochanters black, tarsi fuscous. Wings (Fig. 51) hyaline, media and cubitus without setæ; base of $R_{s}$ distad of the midpoint between humerus and the tip of $R_{1} ; R_{1}$ ends far proximad of the 
forking of $\mathrm{M}$; petiole of cubitus shorter than half the length of the base of $\mathrm{M}$; costa extends less than half the distance between the tips of $R_{8}$ and $M_{1} ; R_{s}$ ends slightly proximad of .85 the length of the wing and considerably proximad of the tip of $\mathrm{M}_{2}$. Halteres fuscous.

This species is near fatigans in the key, but differs by having fuscous halteres, a shorter costa and a shorter cubitus petiole.

Described from one male, collected at Felton, St. Cruz Mts., Cal., May 15-19, 1907, by J. C. Bradley. Type No. 225.

\section{Neosciara pilata n. sp.}

Male: Length, $1.4 \mathrm{~mm}$. Head somewhat shining, black; antennæ fuscous; palpi luteous. Thorax somewhat shining, almost black. Abdomen dark fuscous. Hypopygium fuscous, with no cluster of setæ on the mid-ventral line at base; clasper (Fig. 21) conical, with 3 apical stout spines, no subapical spines, and several small setæ on the inner margin. Legs: coxæ and femora luteous, trochanters black, tibiæ fulvous; tarsi fuscous. Wings (Fig. 52) hyaline; media and cubitus without setæ; base of $R_{s}$ distad of the mid-point between humerus and the tip of $R_{1} ; R_{1}$ ends far proximad of the forking of $M$; petiole of cubitus a little less than half the length of the base of $M$; costa extends more than half the distance between the tips of $R_{s}$ and $M_{1} ; R_{s}$ ends distad of .85 the length of the wing and slightly proximad of the tip of $\mathrm{M}_{2}$. Halteres; knobs fuscous, pedicels luteous.

This species is very similar to trifurca, but differs in size, in the longer costa and cubitus petiole, and in the position of $R_{2}$ in relation to that of $\mathrm{M}_{2}$.

Described from one male, collected at Felton, St. Cruz Mts., Cal., May 15-19, '07, by J. C. Bradley. Type No. 226.

\section{Neosciara ericia n. sp.}

Male: Length, $2.9 \mathrm{~mm}$. Head black, somewhat shiny; antennæ fuscous, about two-thirds the length of the body; palpi fuscous. Thorax fuscous, somewhat shiny. Abdomen almost black. Hypopygium fuscous, with no cluster of setæ on the mid-ventral line at base; clasper (Fig. 22) globose, with no stout spines. Legs: coxæ fulvous, femora and tibiæ brown, tarsi fuscous. Wings (Fig. 53) hyaline; cubitus and media with no setæ; base of $\mathrm{R}_{\mathrm{s}}$ distad of the mid-point between the humerus and the tip of $R_{1} ; R_{1}$ proximad of the forking of media; petiole of cubitus much less than half the length of the basal section of $\mathrm{M}$; costa extends over two-thirds the distance between the tips of $\mathrm{R}_{\mathrm{s}}$ and $\mathrm{M}_{1} ; \mathrm{R}_{\mathrm{s}}$ ends distad of .85 the length of the wing, and about opposite the tip of $\mathrm{M}_{2}$. Halteres fuscous.

This species is near longispina in the key, but differs by having no stout spine on the clasper, and by having a shorter cubitus petiole.

Described from one male collected at Brookline, Mass., by C. W. Johnson. Type No. 227. 
23. Neosciara penna n. sp.

Male: Length, $1.1 \mathrm{~mm}$. Head black, somewhat shiny; antennæ fuscous, over half the length of the body; palpi luteous. Thorax somewhat shining, almost black. Abdomen dark fuscous with posterior margin of the intermediate segments dull luteous. Hypopygium fuscous, with no cluster of setæ on the mid-ventral line at the base; clasper (Fig. 23) narrowly oval, with one apical stout spine and no subapical spines. Legs; coxæ and femora luteous, trochanters black, tibiæ and tarsi fuscous. Wings (Fig. 54) hyaline; media and cubitus without setæ; base of $\mathrm{R}_{\mathrm{s}}$ distad of the mid-point between the humerus and the tip of $R_{1} ; R_{1}$ ends considerably proximad of the forking of $M$; petiole of cubitus shorter than half the length of the base of $\mathrm{M}$; costa extends more than half the distance between the tips of $R_{s}$ and $M_{1} ; R_{s}$ ends slightly proximad of .85 the length of the wing and considerably proximad of $\mathrm{M}_{2}$. Halteres, knob fuscous, pedicel luteous.

This species is near acuta in the key but differs from the latter by having no subapical spines on the clasper and by having $\mathrm{R}_{\mathrm{s}}$ end proximad of the tip of $\mathrm{M}_{2}$. Type No. 228 .

Described from one male, collected at Blue Lake, Humboldt Co., Cal., June 20-27, by J. C. Bradley.

\section{Neosciara pollicis n. sp.}

Male: Length, $1.4 \mathrm{~mm}$. Head somewhat shiny, black; antennæ fuscous, about half the length of the body; palpi fuscous. Thorax somewhat shining, fuscous. Abdomen almost black. Hypopygium fuscous, with no cluster of setæ on the mid-ventral line at base; clasper (Fig. 24) longer than wide, with no stout spines, but with a subapical long seta. Legs: coxæ and femora fulvous, trochanters black; tibiæ and tarsi dull brown. Wings (Fig. 55) brownish; cubitus and media without setæ; base of $R_{s}$ distad of the mid-point between the humerus and the tip of $R_{1} ; R_{1}$ ends proximad of the forking of $M$; petiole of cubitus almost as long as the base of media; costa extends a little over half the distance between the tips of $R_{s}$ and $M_{1} . R_{s}$ ends proximad of .85 the length of the wing and noticeably proximad of the tip of $\mathrm{M}_{2}$. Halteres dark fuscous.

This species is near sative and may be distinguished from the latter especially by having a wider wing and by the clasper lacking spines.

Described from one male collected in Arizona, August. Type No. 229.

\section{Neosciara hamata n. $\mathrm{sp}$.}

Male: Length, $1.2 \mathrm{~mm}$. Head shining, black; antennæ fuscous; palpi fuscous. Thorax shiny, almost black. Abdomen almost black. Hypopygium almost black, with no cluster of setæ on the mid-ventral 
line at base; clasper (Fig. 25) at least twice as long as wide, with one large apical spine, and no subapical spines. Legs fuscous; the front coxæ fulvous. Wings (Fig. 56) hyaline; cubitus and media with no setæ; base of $R_{\mathrm{s}}$ considerably distad of the mid-point between humerus and the tip of $R_{1} ; R_{1}$ ends far proximad of the forking of $M$; petiole of cubitus a little longer than half the length of the base of media; costa extends about half the distance between the tips of $R_{s}$ and $M_{1} ; R_{s}$ ends distad of .85 the length of the wing, and noticeably proximad of the tip of $\mathrm{M}_{2}$. Halteres fuscous.

This species is near actuosa in the key, but differs especially in the form of the clasper, which is longer, narrower and more blunt at the tip.

Described from one male, collected by J. C. Bradley at Black Rock Mt., Georgia, at an altitude of 3,500 feet, May 20-25, 1911. Type No. 230.

\section{Neosciara felti n. sp.}

Male: Length, $1 \mathrm{~mm}$. Head shiny black; antennæ dark fuscous; palpi fuscous. Thorax shiny black. Abdomen dark fuscous. Hypopygium fuscous, with no cluster of setæ on the mid-ventral line at base; clasper (Fig. 26) about twice as long as wide, with one very stout apical spine, and about 5 more slender subapical spines, the most proximad of which is longer and more slender than the others. Legs: coxæ and femora fulvous to luteous, trochanters black, tibiæ and tarsi fuscous. Wings (Fig. 57) hyaline; media and cubitus without setæ; base of $R_{s}$ far distad of the mid-point between humerus and the tip of $R_{1} ; R_{1}$ ends far proximad of the forking of $\mathrm{M}$; petiole of cubitus over half as long as the basal section of media; costa extends about two-thirds the distance between the tips of $R_{s}$ and $M_{1} ; R_{s}$ ends distad of .85 the length of the wing and between the tips of $R_{s}$ and $M_{1} ; R_{s}$ ends distad of .85 the length of the wing and about opposite the tip of $\mathrm{M}_{2}$. Halteres fuscous.

Described from one male collected at Ithaca, N. Y., July 9, 1904. Type No. 231.

\section{Neosciara macroptera n. $\mathrm{sp}$.}

Male: Length, $1.5 \mathrm{~mm}$. Head somewhat shining, black, antennæ fuscous; palpi fuscous. Thorax somewhat shiny, fuscous. Abdomen almost black. Hypopygium fuscous, with no cluster of setæ on the mid-ventral line at base; clasper (Fig. 27) at least twice as long as wide, with one stout apical spine and about 8 subequal much smaller subapical spines on the inner margin. Legs; coxæ fulvous, trochanters black, femora, tibiæ and tarsi fuscous. Wings (Fig. 58) hyaline, with no setæ on the media and cubitus; base of $R_{\mathrm{s}}$ considerably distad of the mid-point between humerus and the tip of $R_{1} ; R_{1}$ ends proximad of the forking of $\mathrm{M}$; petiole of cubitus a little over half the length of the base 
of media; costa extends a little over half the distance between the tips of $R_{s}$ and $M_{1} ; R_{s}$ ends slightly distad of .85 the length of the wing and distinctly proximad of the tip of $\mathrm{M}_{2}$. Halteres; knobs fuscous, pedicels luteous.

This species differs from felti by having a clasper with no long subapical spines.

Described from one male collected by J. C. Bradley at Felton, St. Cruz Mts., Cal., May 15-19, at an elevation of 300-500 feet. Type No. 232.

\section{Neosciara subtrivialis n. sp.}

Male: Length, $1.5 \mathrm{~mm}$. Head somewhat shining, black; antennæ fuscous, a little over half the length of the body; palpi fulvous. Thorax somewhat shiny, fuscous. Abdomen fuscous. Hypopygium fuscous, with no cluster of setæ on the mid-ventral line at base; clasper (Fig. 28) at least twice as long as wide, with about 3 stout apical spines, no subapical spines, and several minute subapical setæ along the inner margin. Legs: coxæ and femora dull fulvous, trochanters black, tibiæ and tarsi fuscous. Wings (Fig. 59) hyaline, media and cubitus without setæ; base of $R_{s}$ distad of the mid-point between humerus and the tip of $R_{1}$; $R_{1}$ ends far proximad of the forking of $M$; petiole of cubitus about half as long as the basal section of $\mathrm{M}$; costa extends about two-thirds the distance between the tips of $R_{s}$ and $M_{1} ; R_{s}$ ends distad of .85 the length of the wing and slightly proximad of the tip of $\mathrm{M}_{2}$. Halteres; knobs fuscous, pedicels luteous.

This species is near trivialis in the key, differing from the latter by having 3 stout apical spines on the clasper and a shorter cubitus petiole.

Described from 2 males, collected at Berkeley, Cal., Oct. 31, 1906, by J. C. Bradley. Type No. 233. One holotype and one paratype.

\section{Neosciara sexdentata n. sp.}

Male: Length, $2 \mathrm{~mm}$. Head black, not shining; antennæ fuscous, half the length of the body; palpi luteous. Thorax not shiny, almost black. Abdomen dark fuscous. Hypopygium fuscous, with no cluster of setæ on the mid-ventral line at base; clasper (Fig. 29) about twice as long as wide at widest part, about 6 apical stout spines and no subapical spines, several minute subapical setæ. Legs: coxæ fulvous; femora, tibiæ and tarsi fuscous; trochanters black. Wings (Fig. 60) hyaline; cubitus and media with no setæ; base of $R_{s}$ distad of the mid-point between the humerus and the tip of $R_{1} ; R_{1}$ proximad of the forking of $\mathrm{M}$; petiole of cubitus almost as long as the basal section of media; costa extends about half the distance between the tips of $R_{s}$ and $M_{1}$; $\mathrm{R}_{\mathrm{s}}$ ends distad of .85 the length of the wing, and slightly proximad of the tip of $\mathrm{M}_{\mathbf{2}}$. Halteres; knobs fuscous, pedicels luteous. 
This species is near impatiens in the key, and differs from the latter by having no spine separated from the rest on the clasper, and a more retracted costa.

Described from one male collected at Santa Paula, Cal. Type No. 234.

\section{Neosciara perfecta n. sp.}

Male: Length, $1.8 \mathrm{~mm}$. Head black, somewhat shiny; antennæ fuscous, about half the length of the body, segments of flagellum not twice as long as wide except at tip; palpi fulvous. Thorax somewhat shining, fuscous. Abdomen fuscous. Hypopygium fuscous, with no cluster of setæ on the mid-ventral line at the base; clasper (Fig. 30) with numerous comparatively short setæ at the apex, and with no stout spines. Legs fulvous, tibiæ and tarsi fuscous. Wings (Fig. 61) hyaline; cubitus and media without setæ; base of $\mathrm{R}_{\mathrm{s}}$ distad of the mid-point between the humeral cross vein and the tip of $R_{1} ; R_{1}$ ends proximad of the forking of $\mathrm{M}$; petiole of cubitus a little less than half the length of the basal section of $\mathrm{M}$; costa extends about two-thirds the distance between the tips of $\mathrm{R}_{\mathrm{s}}$ and $\mathrm{M}_{1} ; \mathrm{R}_{\mathrm{s}}$ ends distad of .85 the length of the wing, and proximad of the tip of $\mathrm{M}_{2}$. Halteres luteous,

This species is near coprophila in the key, but differs from the latter especially by having a shorter cubitus petiole, yellow halteres, and shorter apical setæ on the clasper.

Described from one male specimen collected in Maryland, April 12, 1914. Type No. 235.

\section{New Species of Sciarids from South, America.}

By F. W. Pettey, Cornell University, Ithaca, N. Y.

Sciara paradoxa n. sp.

Male: Length, $2.8 \mathrm{~mm}$. Head black; antennæ and palpi black. Thorax black, somewhat shining, with whitish powdery covering. Abdomen black. Hypopygium black, with no cluster of setæ on the mid-ventral line at base; clasper (Fig. 65) at least twice as long as wide, with one large and about 4 smaller but stout apical spines, and one larger subapical spine. Legs: coxæ black, femora and tibiæ dark fuscous, tarsi black. Wings (Fig. 64) smoky brown, with cubitus and media setose and second anal vein indicated by a row of setæ; base of $R_{s}$ at about the mid-point between the humeral cross vein and the tip of $R_{1} ; R_{1}$ ends opposite or slightly distad of the forking of $M$; petiole of cubitus one-third of its length longer than the basal section of $\mathrm{M}$; costa extends about one-third the distance between $\mathrm{R}_{\mathrm{s}}$ and $\mathrm{M}_{1}$; $R_{s}$ ends considerably distad of .85 the length of the wing, and slightly proximad of the tip of $\mathrm{M}_{2}$. Halteres black. 
This species possesses a structural character unknown to the writer in any other species of Sciara, i. e., a row of setæ forming apparently a second anal vein.

Described from 3 males collected at Valle de Papas, Coqueta, Columbia, South America, March, 1912. Type No. 237. Two paratypes. Cornell University collection.

\section{Neosciara columbia n. sp.}

Male: Length, $1.2 \mathrm{~mm}$. Head black, dull; antennæ fuscous, over half the length of the body, segments of flagellum twice as long as wide; palpi fuscous. Thorax dull, fuscous. Abdomen fuscous to black. Hypopygium fuscous, with 2 clusters of setæ no larger than the surrounding setæ, one cluster on each side of the mid-ventral line at the base (Fig. 63b); clasper (Fig. 63a) over twice as long as wide, with no stout spines, and with about 2 subapical long setæ on the inner margin. Legs fuscous; tibiæ and tarsi darker than coxæ and femora. Wings (Fig. 66) smoky brown; cubitus and media with no setæ; base of $R_{s}$ distad of mid-point between the humeral cross vein and the tip of $R_{1}$; $R_{1}$ ends proximad of the forking of $\mathrm{M}$; petiole of cubitus as long as the basal section of $\mathrm{M}$; costa extends at least two-thirds the distance between $R_{s}$ and $M_{1} ; R_{s}$ ends proximad of .85 the length of the wing and far proximad of the tip of $\mathrm{M}_{2}$. Halteres; knobs fuscous, pedicels fulvous.

Described from 4 males collected at La Sierra, Columbia, South America, March 1, 1912. Type No. 238. Three paratypes. Cornell University collection. 


\section{EXPLANATION OF PLATES XXX AND XXXI.}

Figures 1 to 31 , inclusive, and Figures 63,65 and 67 are from camera lucida drawings, much enlarged, each figure representing a clasper of the genitalia of a male. Figures 32 to 62 inclusive and Figures 64 and 66 are photomicrographs of the right wing of each species of male.

Fig. 1. Sciara forceps n. sp.

Fig. 2. Sciara multisetifera n. sp.

Fig. 3. Sciara cylindrica n. sp.

Fig. 4. Sciara congregata Joh.

Fig. 5. Sciara psittacus n. sp.

Fig. 6. Sciara habilis var.

Fig. 7. Sciara globosa n. sp.

Fig. 8. Neosciara falcata n. sp.

Fig. 9. Neosciara fochi $\mathrm{n}$. sp.

Fig. 10. Neosciara joffrei n. sp.

Fig. 11. Neosciara quadrispinosa n. sp.

Fig. 12. Neosciara luteola n. sp.

Fig. 13. a, b, Neosciara lobosa n. sp.

Fig. 14. a, b, Neosciara petaini n. sp.

Fig. 15. a, b, Neosciara grandis n. sp.

Fig. 16. a, b, Neosciara trifolii n. sp.

Fig. 17. a, b, Neosciara polychaeta n.sp.

Fig. 18. a, b, Neosciara conglomerata

$$
\text { n. sp. }
$$

Fig. 19. Neosciara ovata n. sp.

Fig. 20. Neosciara trifurca n. sp.

Fig. 21. Neosciara pilata n. sp.

Fig. 22. Neosciara ericia n. sp.

Fig. 23. Neosciara penna n. sp.

Fig. 24. Neosciara pollicis n. sp.

Fig. 25. Neosciara hamata n. sp.

Fig. 26. Neosciara felti n. sp.

Fig. 27. Neosciara macroptera n. sp.

Fig. 28. Neosciara subtrivialis $\mathrm{n}$. $\mathrm{sp}$.

Fig. 29. Neosciara sexdentata n. sp.

Fig. 30. Neosciara perfecta n. sp.

Fig. 31. Neosciara caldaria var.

Fig. 32. Sciara forceps n. sp.
Fig. 33. Sciara multisetifera n. sp.

Fig. 34. Sciara cylindrica n. sp.

Fig. 35. Sciara congregata n. sp.

Fig. 36. Sciara psittacus n. sp.

Fig. 37. Sciara habilis var.

Fig. 38. Sciara globosa n. sp.

Fig. 39. Neosciara falcata n. sp.

Fig. 40. Neosciara fochi n. sp.

Fig. 41. Neosciara joffrei n. sp.

Fig. 42. Neosciara quadrispinosa n. sp.

Fig. 43. Neosciara luteola n. sp.

Fig. 44. Neosciara lobosa n. sp.

Fig. 45. Nesociara petaini n. sp.

Fig. 46. Neosciara grandis n. sp.

Fig. 47. Neosciara trifolii n. sp.

Fig. 48. Neosciara polychaeta n. sp.

Fig. 49. Neosciara conglomerata n. sp.

Fig. 50. Neosciara ovata n. sp.

Fig. 51. Neosciara trifurca n. sp.

Fig. 52. Neosciara pilata n. sp.

Fig. 53. Neosciara ericia n. sp.

Fig. 54. Neosciara penna n. sp.

Fig. 55. Neosciara pollicis n. sp.

Fig. 56. Neosciara hamata n. sp.

Fig. 57. Neosciara felti n. sp.

Fig. 58. Neosciara macroptera n. sp.

Fig. 59. Neosciara subtrivialis n. sp.

Fig. 60. Neosciara sexdentata n. sp.

Fig. 61. Neosciara perfecta n. sp.

Fig. 62. Neosciara caldaria var.

Fig. 63. a, b, and Fig. 66, Neosciara columbia n. Sp.

Fig. 64, 65. Sciara paradoxa n. sp. 


\section{$2 \mathrm{BHL}$ Biodiversity Heritage Library}

Pettey, F W . 1918. "A Revision of the Genus Sciara of the Family Mycetophilidae (Diptera)." Annals of the Entomological Society of America 11, 319-343. https://doi.org/10.1093/aesa/11.4.319.

View This Item Online: https://www.biodiversitylibrary.org/item/44520

DOI: https://doi.org/10.1093/aesa/11.4.319

Permalink: https://www.biodiversitylibrary.org/partpdf/193585

\section{Holding Institution}

Smithsonian Libraries

\section{Sponsored by}

Smithsonian

\section{Copyright \& Reuse}

Copyright Status: NOT_IN_COPYRIGHT

This document was created from content at the Biodiversity Heritage Library, the world's largest open access digital library for biodiversity literature and archives. Visit BHL at https://www.biodiversitylibrary.org. 